\title{
Underground Innovation: How to Encourage Bootlegging Employees to Disclose Their Good Ideas
}

\author{
Kamal Sakhdari and Erfan Jalali Bidakhavidi
}

\author{
(6 Hidden talent counts for nothing. ") \\ Nero (37 AD - 68 AD) \\ Roman Emperor
}

\begin{abstract}
Employees are increasingly considered as the origin of many corporate entrepreneurial ideas. Research on "bootlegging" posits that individuals often resort to hidden activities to elaborate their initial ideas and bring them to fruition. The origins and causes of bootlegging behaviour are well argued in the literature. Yet, less is known about what drives bootleggers to uncover their hidden ideas. This research uses field data from in-depth interviews with innovators in R\&D departments in different industries of Iran to identify factors stimulating bootleggers to reveal their underground ideas. We identified five groups of factors at individual, managerial, firm, industrial, and idea levels, explaining the revealing stage of bootlegging behaviour. The findings provide a better understanding of the later phases of bootlegging behaviour and the possible role of context-specific factors such as cultural and religious beliefs.
\end{abstract}

\section{Introduction}

The corporate entrepreneurship and innovation literature has increasingly highlighted the role of individuals in stimulating entrepreneurial activities within established firms (Amabile, 1988; Kanter, 2000; Turner \& Pennington III, 2015). In his seminal article, Burgelman (1983) posits that corporate entrepreneurship is mainly commenced with bottom-up, exploratory activities undertaken by employees at lower levels, in particular those operating at the exploratory departments in $R \& D$ units. Yet, where individuals encounter a lack of formal support for elaborating their ideas, they may resort to "underground" (Aram, 1973), "bootlegging" (Augsdorfer, 1996, 2012), or "creative deviance" (Mainemelis, 2010) behaviours. These terms, used interchangeably in this article and the literature (Criscuolo et al., 2013), refer to the process by which employees secretly work on ideas which are not formally supported by their organizations (Augsdorfer, 2005).

The literature on bootlegging has mostly investigated factors causing individuals to follow their underground ideas (Abetti, 1999; Augsdorfer, 2008, 1996, 2012; Glob- ocnik \& Salomo, 2015; Koch \& Leitner, 2008; Masoudnia \& Szwejczewski, 2012; Salomo \& Mensel, 2001). Individuals tend to undertake bootlegging behaviour to reduce uncertainty associated with their ideas (Masoudnia \& Szwejczewski, 2012), show the technological and market potential of their ideas (Criscuolo et al., 2013) and establish legitimacy for subsequent resource acquisition (Kannan-Narasimhan, 2014). Yet, there is less understanding of the reasons why bootleggers prefer to uncover their hidden ideas. This lack of attention is unfortunate, given that empirical evidence indicates that bootlegging activities and the subsequent internal pursuit of underground ideas can lead to innovative and entrepreneurial outputs for firms (Augsdorfer, 1996; Burgelman \& Sayles, 1986; Criscuolo et al., 2013; Ryan, 2005). Moreover, prior studies have mostly examined such behaviour in developed contexts and said relatively little about how contextual factors may affect bootlegging activities.

This study addresses this gap by posing the question of why bootleggers choose to reveal their elaborated ideas. Data for this research comes from in-depth interviews with bootleggers working in $R \& D$ departments in 


\section{How to Encourage Bootlegging Employees to Disclose Their Good Ideas}

\section{Kamal Sakhdari and Erfan Jalali Bidakhavidi}

15 firms in the developing context of Iran. The results indicate that factors at individual, managerial, organizational, industrial, and idea levels can explain the revealing stage of bootlegging.

This study makes at least two important contributions to the bootlegging literature. First, whereas prior literature has largely focused on why employees undertake hidden activities (Augsdorfer, 2005; Masoudnia \& Szwejczewski, 2012), this research enriches the literature by investigating the later phases of such behaviour and the reasons behind uncovering hidden ideas. Second, prior studies have been predominately conducted in the context of developed contexts and provided little understanding of how contextual factors may affect bootlegging activities. Selecting the developing country of Iran, we provide valuable insights into context-specific factors driving bootlegging activities.

\section{Theoretical Background}

Bootlegging refers to an unofficial way of pursuing innovative activities when facing organizational obstacles (Knight, 1967). Similarly, Augsdorfer (1996) defines bootlegging as a deviate behaviour hidden from senior managers whereby organizational time and resources are used for pursuing innovative ideas that are mainly in line with organisational goals and benefits. Accordingly, bootlegging activities hold three important characteristics(Criscuolo et al., 2013):

1. They are secret and hidden from top management, and not necessarily from colleagues and line managers.

2. They consist of non-programmed and bottom-up activities, often undertaken by employees operating at lower levels of the firm such as those working in R\&D units.

3. They represent a kind of constructive deviance, and the resulting goals and innovations are legitimate even though the means may be illegitimate.

Explaining the roots of this behaviour in the theory of "structural strain", Merton (1968) states that there are valuable goals in any organization and employees attempt to achieve those goals. In a supportive firm where the legitimate means are provided, employees tend to use those means to accomplish internalized goals. On the other hand, when employees are en- countered with a dearth of legitimate means, and there is the so-called "structural strain", they may resort to illegitimate means to achieve organizational goals such as entrepreneurial activities. Merton (1968) posits that conformity is an expected behaviour when employees are not faced with structural strain. In this situation, employees follow the rules and use available means to achieve organizational goals. Yet, employees may undertake deviant behaviour when legitimate means are not available for pursuing promoted goals. Meinamelis (2010) argues that structural strain is common in firms due to resource restrictions and the fact that firms often over-promote innovation and creativity and give less attention to available resources for supporting innovative ideas.

Empirical studies have examined bootlegging behaviour and the reasons why employees undertake such activities. A summary of these studies is presented in Table1. In his seminal article, Burgelman (1983) argues that "hidden innovative activities" are primarily undertaken for elaborating ideas that are beyond the core business of a firm. If the structural and strategic conditions are not appropriate for pursuing innovative ideas, bootlegging occurs and it will continue until the idea can prove its value to senior managers. Augsdorfer (1996, 2008) also posits that employees bootleg to elaborate their immature ideas. When the economic justification and feasibility of the idea is vague, the bootlegging process continues, yet once the feasibility is proven, the process may terminate. Bootlegging is more common in organizations that do not support experimental trial. Employees also resort to bootlegging behaviour in inflexible planning systems where R\&D budgets are assigned periodically and ideas appearing between planning periods are not supported (Augsdorfer, 2008).

Abetti (1997) argues that bootlegging can be an effective way of escaping rigid and time-consuming processes, and avoiding interference from managers. It is also considered as a suitable approach for protecting ideas (Koch \& Leitner, 2008). Masoudnia and Szwejczewski (2012) find that bootlegging is undertaken to diminish uncertainty associated with ideas. Bootleggers go underground to establish legitimacy and hence acquire needed resources for elaborating their ideas (Kannan-Narasimhan, 2014). Bootlegging can also be affected by formal management practices such as strategic autonomy and rewards as well as employees' selfefficacy (Globocnik \& Salomo, 2015) and creativity (Augsdorfer, 2012). 


\section{How to Encourage Bootlegging Employees to Disclose Their Good Ideas}

\section{Kamal Sakhdari and Erfan Jalali Bidakhavidi}

Table 1. A summary of key prior research on bootlegging

\begin{tabular}{|c|c|c|}
\hline Author(s) & Year & Findings \\
\hline Burgelman & 1983 & $\begin{array}{l}\text { Bootlegging is a response to non-supportive structural and strategic conditions for ideas } \\
\text { outside of a firm's core business. }\end{array}$ \\
\hline Augsdorfer & 1996 & $\begin{array}{l}\text { Bootlegging behaviour is undertaken to show the economic justification and feasibility of the } \\
\text { idea. }\end{array}$ \\
\hline Pearson & 1997 & $\begin{array}{l}\text { Bootlegging can result from curiosity, solving technical issues, and showing the viability of } \\
\text { the idea. }\end{array}$ \\
\hline Abetti & 1997 & Bootlegging is an effective way of escaping rigid and time-consuming procedures and rules. \\
\hline Kanter & 2000 & Bootlegging is done to gain support for risky projects. \\
\hline Augsdorfer & 2005 & $\begin{array}{l}\text { The aim of bootlegging is pre-search, product/process improvement and development, and } \\
\text { problem solving. }\end{array}$ \\
\hline Augsdorfer & 2008 & $\begin{array}{l}\text { Lack of support for experimental trial and inflexible planning are the main reasons for } \\
\text { bootlegging. }\end{array}$ \\
\hline Koch \& Leitner & 2008 & Bootlegging is a path towards protecting ideas. \\
\hline $\begin{array}{l}\text { Masoudnia \& } \\
\text { Szwejczewski }\end{array}$ & 2012 & Bootlegging is undertaken to diminish uncertainty associated with ideas. \\
\hline Augsdorfer & 2012 & Bootleggers can be identified using a diagnostic personality test. \\
\hline Kannan-Narasimhan & 2014 & $\begin{array}{l}\text { Bootleggers aim to establish legitimacy and hence acquire needed resources for elaborating } \\
\text { their ideas. }\end{array}$ \\
\hline Globocnik \& Salomo & 2015 & Formal management practices and employees' self-efficacy trigger bootlegging behaviour. \\
\hline
\end{tabular}

The literature review reveals that prior studies lean more towards the earlier phases of bootlegging behaviour, and less is known about factors stimulating bootleggers to reveal their hidden ideas. Moreover, Abetti's (1999) study indicates that bootlegging behaviour is more common among Japanese employees than American employees because Japanese culture put greater value on long-term employment and loyalty to the firm. As such, cultural and institutional factors may also explain bootlegging activities, but this point has received little attention in prior research. Thus, these gaps in the literature provide the opportunity for this study to further investigate the revealing stage of bootlegging.

\section{Research Methods}

This study adopts a qualitative approach to answer the research questions. The qualitative approach tends to be chosen when the researcher aims to gain a deeper understanding of the phenomenon or identify mechanisms behind it. The nature of qualitative research is essentially exploratory. These studies are conducted for obtaining deep and basic knowledge about a new or complex issue. A case study strategy tends to be applied in exploratory phases when the researcher aims to gain deeper insights into the issue, asking how and why questions (Yin, 2013).

Prior studies indicate that bootlegging behaviour is more common in such industries as information technology, pharmaceutics, medicine, and telecommunication (Masoudnia \& Szwejczewski, 2012). Accordingly, for this study, individuals were selected from companies operating in the field of information technology, software, and pharmaceutics. Following KannanNarasimhan (2014), given that bootleggers are by defini- 


\section{How to Encourage Bootlegging Employees to Disclose Their Good Ideas}

\section{Kamal Sakhdari and Erfan Jalali Bidakhavidi}

tion hidden, we approached top managers to help us identify employees who are more likely to be involved with bootlegging behaviour. They are typically innovators at knowledge-creation units such as $R \& D$ and product development units. We interviewed 18 employees in 15 firms, and each interview lasted between 60 to 90 minutes each. Many of the employees were followed up with a second interview, resulting in a total of 33 interviews. Table 2 profiles the companies participants.

\section{Reliability and validity of the research}

In qualitative studies, reliability refers to the possibility of repeating the same research by another independent researcher and extracting similar results from the same data (Yin, 2013). In this study, following Yin (2013), we documented the data collection and analysis processes so that other researchers could follow and check the process of deriving the results from data. For example, Tables 3 to 7 illustrate open and axial coding, selected quotation, and author's notes. Moreover, we increased the reliability of research by employing two persons for coding the transcript and by re-checking the data with the participants. Internal validity concerns the extent to which the results and interpretations are correct and based on reality rather than being the researcher's speculations. There are several strategies for increasing the internal validity of a qualitative study such as triangulating researchers and peer and participant checking, which were all applied in this study. External validity refers to the theoretical generalizability of the data, which is substantially achieved through using several case studies for reaching theoretical saturation (Yin, 2013), which was adopted in this research.

\section{Results}

Following Corbin and Strauss (2014), open and axial coding levels were used to identify first- and second-order codes. Peer and expert briefing was used to validate emerging codes. The identified categories were classified in five major groups including factors related to the individual, manager, organization, idea, and industry. These factors are shown in Tables 3 to 7 . At the individual levels, factors such as persistence, extroversion, practicality, ethics, and self-confidence can be important in revealing underground ideas. The second category is associated with how managers treat their subordinates and manage their units, including the tendency to involve and the development of trust-based relationships. Organizational factors, such as valuing transparency, clarity of organizational values, teamwork and collectivism, and normative enforcement, can also be effective in the revealing stage of bootlegging. Factors related to
Table 2. Characteristics of the companies $(\mathrm{N}=15)$ and interview subjects $(\mathrm{N}=18)$

\begin{tabular}{|c|c|c|c|}
\hline \multicolumn{2}{|c|}{ Gender } & \multicolumn{2}{|l|}{ Unit } \\
\hline Male & $73 \%$ & $\mathrm{R} \& \mathrm{D}$ & $67 \%$ \\
\hline \multirow[t]{2}{*}{ Female } & $27 \%$ & Product Development & $23 \%$ \\
\hline & & Software Development & $10 \%$ \\
\hline \multicolumn{2}{|c|}{ Education Level } & \multicolumn{2}{|l|}{ Firm size } \\
\hline Bachelor's & $67 \%$ & $\leq 49$ employees & $11 \%$ \\
\hline Master's & $27 \%$ & 50-249 employees & $28 \%$ \\
\hline $\mathrm{PhD}$ & $6 \%$ & $\geq 250$ employees & $61 \%$ \\
\hline \multicolumn{2}{|c|}{ Interviewee Age } & \multicolumn{2}{|l|}{ Industry } \\
\hline $21-30$ years & $17 \%$ & Information technology & 4 \\
\hline $31-40$ years & $55 \%$ & Telecommunications & 5 \\
\hline $41-50$ years & $22 \%$ & Medicine & 4 \\
\hline$>50$ years & $6 \%$ & Pharmaceutics & 5 \\
\hline
\end{tabular}

the type of business and the business environment, including the degree of competition and the dynamism of the business environment, can also contribute to revealing hidden ideas. Finally, revealing hidden ideas can be explained by factors related to the idea, such as the relationship to current business and the closeness to implementation.

\section{Discussion and Conclusion}

Prior research shows that the origin of many organizational innovations are "individuals" and primarily reflect a bottom-up and informal process. The literature on bootlegging explains why employees resort to underground activities to elaborate their ideas (Augsdorfer, 1996; 2012; Masoudnia \& Szwejczewski, 2012). Yet, less is known about the reasons behind uncovering hidden ideas, in particular in the context of developing countries. As such, this research was designed to shed light on the revealing stage of bootlegging. As depicted in Figure 1, identified factors can be categorized at individual, managerial, organizational, industrial, and idea levels. 


\section{How to Encourage Bootlegging Employees to Disclose Their Good Ideas}

\section{Kamal Sakhdari and Erfan Jalali Bidakhavidi}

Table 3. Individual factors

\begin{tabular}{lll}
\hline Open Coding & Selected Quotation & Author's Notes \\
\hline Persistence & $\begin{array}{l}\text { That means I should be creative enough to create a } \\
\text { sample of what I want to present, then I can } \\
\text { announce it. }\end{array}$ & $\begin{array}{l}\text { Persistence can enable a person to find alternative } \\
\text { ways to elaborate and express their ideas. }\end{array}$ \\
$\begin{array}{l}\text { Extroversion } \\
\text { versus }\end{array}$ & $\begin{array}{l}\text { Because of my extroverted attitude, I say whatever } \\
\text { comes to my mind easily without using many filters. }\end{array}$ & $\begin{array}{l}\text { Extroverted people uncover their ideas to the } \\
\text { public sooner because they are more comfortable } \\
\text { speaking up. }\end{array}$ \\
\hline $\begin{array}{l}\text { Practicality } \\
\text { Iam pragmatic and I prefer not to say what I am } \\
\text { doing till I have reached a concrete output. }\end{array}$ & $\begin{array}{l}\text { It takes some time for practical employees to reach } \\
\text { concrete outputs, so these people unveil their } \\
\text { ideas later. }\end{array}$ \\
\hline $\begin{array}{l}\text { Ethics } \\
\text { When you do not let managers know you are } \\
\text { spending your time in unplanned activities, it is } \\
\text { against ethics and God's advice. }\end{array}$ & $\begin{array}{l}\text { Believing in ethics, and in particular unlawful } \\
\text { (forbidden) and lawful (permitted) religious issues, } \\
\text { encourages employees to unveil the idea sooner. }\end{array}$ \\
\hline $\begin{array}{l}\text { Self-confidence } \\
\text { Lack of confidence caused me not to come and tell } \\
\text { you what I am doing. }\end{array}$ & $\begin{array}{l}\text { People who have little self-confidence will unveil } \\
\text { their ideas later. }\end{array}$ \\
\hline
\end{tabular}

Table 4. Managerial factors

\begin{tabular}{lll}
\hline Open Coding & Selected Quotation & Author's Notes \\
\hline $\begin{array}{l}\text { Management } \\
\text { involvement }\end{array}$ & $\begin{array}{l}\text { The managers prefer to be informed about what is } \\
\text { going on. I think everything should be told them. }\end{array}$ & $\begin{array}{l}\text { Management involvement encourages } \\
\text { underground ideas to be revealed sooner. }\end{array}$ \\
\hline $\begin{array}{l}\text { Trust-based } \\
\text { relationship }\end{array}$ & $\begin{array}{l}\text { I know if I tell him the idea, he listens to me, so I'd like } \\
\text { to tell him my idea. } \\
\text { Well, I have some fear of presenting it to my supervisor } \\
\text { and he tells it to top managers as his idea. }\end{array}$ & $\begin{array}{l}\text { The managers who develop relationships based on } \\
\text { trust enable employees to reveal their ideas sooner. }\end{array}$ \\
\hline
\end{tabular}

Table 5. Organizational factors

\begin{tabular}{lll}
\hline Open Coding & Selected Quotation & Author's Notes \\
\hline $\begin{array}{l}\text { Valuing } \\
\text { transparency }\end{array}$ & $\begin{array}{l}\text { I have to say everything. We have been told always to } \\
\text { do so. }\end{array}$ & $\begin{array}{l}\text { A culture valuing transparency encourages } \\
\text { employees to uncover their hidden ideas. }\end{array}$ \\
\hline $\begin{array}{l}\text { Clearness of } \\
\text { organizational } \\
\text { values }\end{array}$ & $\begin{array}{l}\text { It is not clear to me what is right and what is wrong. I } \\
\text { am often not sure whether to be creative or follow the } \\
\text { rules. }\end{array}$ & $\begin{array}{l}\text { Lack of awareness about the organizational values } \\
\text { postpones revealing ideas. }\end{array}$ \\
\hline $\begin{array}{l}\text { Teamwork and } \\
\text { collectivism }\end{array}$ & $\begin{array}{l}\text { An individualistic culture makes someone not tell } \\
\text { someone else exactly what is they are doing. }\end{array}$ & $\begin{array}{l}\text { In an individualistic culture, hidden things are } \\
\text { uncovered later. }\end{array}$ \\
\hline $\begin{array}{l}\text { Normative } \\
\text { enforcement }\end{array}$ & $\begin{array}{l}\text { You work freely and independently. No one asks you } \\
\text { Ghat are you doing now or what you did yesterday. } \\
\text { Goals are important, not the means to achieve them. }\end{array}$ & $\begin{array}{l}\text { Low normative enforcement encourages revealing } \\
\text { hidden ideas. }\end{array}$
\end{tabular}




\section{How to Encourage Bootlegging Employees to Disclose Their Good Ideas}

\section{Kamal Sakhdari and Erfan Jalali Bidakhavidi}

Table 6. Industry/business environment-related factors

\begin{tabular}{lll}
\hline Open Coding & Selected Quotation & Author's Notes \\
\hline $\begin{array}{l}\text { Degree of } \\
\text { competition }\end{array}$ & $\begin{array}{l}\text { Because this business is so competitive and other } \\
\text { companies might surpass us, it is constantly } \\
\text { emphasized to know everyone's ideas. }\end{array}$ & $\begin{array}{l}\text { In competitive environments, employees are more } \\
\text { likely to be encouraged to present their ideas, so they } \\
\text { uncover their ideas sooner. }\end{array}$ \\
\hline $\begin{array}{l}\text { Dynamism of } \\
\text { the business } \\
\text { environment }\end{array}$ & $\begin{array}{l}\text { He (the manager) should be aware of it because if I } \\
\text { decide not to tell him today, it might be late tomorrow }\end{array}$ & $\begin{array}{l}\text { Employees should uncover their ideas sooner in } \\
\text { more dynamic and fast-paced business } \\
\text { environments. }\end{array}$ \\
\hline
\end{tabular}

Table 7. Idea-related factors

\begin{tabular}{lll}
\hline Open Coding & Selected Quotation & Author's Notes \\
\hline $\begin{array}{l}\text { Relationship to } \\
\text { current business }\end{array}$ & $\begin{array}{l}\text { It solves a challenge we are faced with in our ongoing } \\
\text { business activities, so why do they reject it? }\end{array}$ & $\begin{array}{l}\text { Ideas related to the core business of the company } \\
\text { will be unveiled sooner. }\end{array}$ \\
\hline $\begin{array}{l}\text { Closeness to } \\
\text { implementation }\end{array}$ & $\begin{array}{l}\text { When I feel like the idea is close to implementation, I } \\
\text { go for telling my supervisors. } \\
\begin{array}{l}\text { Much money is needed to do it, and if I present it } \\
\text { now, it will be rejected for sure, so I decide not to } \\
\text { present it for now. }\end{array}\end{array}$ & $\begin{array}{l}\text { Ideas that are well developed and close to } \\
\text { implementation are revealed sooner. }\end{array}$ \\
\hline
\end{tabular}

We found that individual factors can be effective in revealing hidden ideas. For example, persistence enables employees to find many alternative ways to follow up their ideas. Extroverted people make their ideas open and public sooner because they are more comfortable speaking up. If morality is important for a person, they may publicize the idea earlier because the hidden work would be against their ethical beliefs. In contrast, employees with low self-confidence may postpone revealing their ideas. Although firms do not have control over many of these individual factors, some of these aspects can be manipulated through human resource practices (Augsdorfer, 2012). An interesting finding of this research is the potential role of ethical and religious beliefs in revealing hidden ideas, thereby opening a compelling avenue for future research to investigate the role of religiosity and ethics in bootlegging behaviour.

The second category is associated with how managers treat their subordinates. For instance, if an employee has the perception that their manager is involved and controls the situation, they may try to publicize the idea earlier. Similarly, managers who listen to subordinates' ideas make them feel comfortable and encourage employees to publicize their hidden ideas sooner. If em-

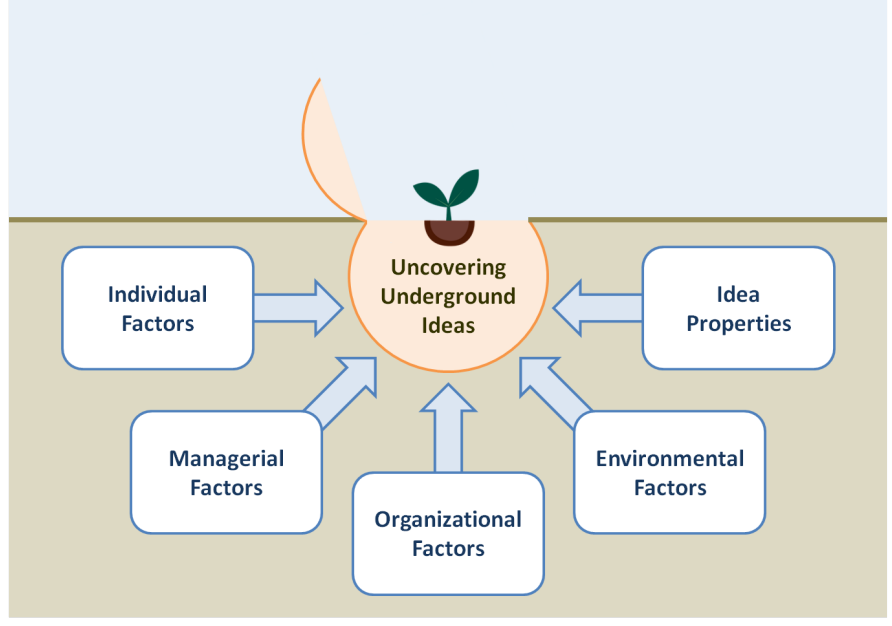

Figure 1. Factors related to uncovering hidden ideas

ployees feel that their managers are likely to steal their ideas (e.g., by presenting the idea to higher level managers without acknowledging the employee's contribution), they may not reveal their hidden ideas. As such, a manager's relational skills and ability to establish relationships based on mutual trust may motivate employees to reveal their underground ideas. Bergelman (1983) argues that middle managers, as intermediaries between senior managers and front line knowledge- 


\section{How to Encourage Bootlegging Employees to Disclose Their Good Ideas}

\section{Kamal Sakhdari and Erfan Jalali Bidakhavidi}

creating staff (e.g., those in marketing and R\&D units), play a critical role in facilitating bottom-up initiatives. Our research reveals that such factors as managers' relational skills can be important in creating a suitable strategic context for elaborating and uncovering hidden ideas.

Organizational factors can also be effective in the revealing stage of bootlegging. Theorizing on deviant creative theory, Mainemelis (2010) argues that strict normative enforcement can hinder bootlegging behaviour. Our research acknowledges this proposition by providing qualitative evidence that greater focus on goals than means may better motivate employees to reveal their elaborated ideas. Cultural factors such as the importance of transparency, clarification of organizational values, and the encouragement of teamwork can also trigger employees to reveal their underground ideas.

Factors related to the type of business and the business environment can also contribute to revealing hidden ideas. For example, in a competitive industry, creativity and the presentation of ideas are encouraged and employees are more likely to unveil their ideas easier and faster because the organization encourages them to do so. In some industries, such as information technology, rapid changes may make revealing ideas more important. As such, it seems that, in business settings with more degree of competition and dynamism, there is greater necessity and pressure to reveal hidden ideas.

Finally, factors related to the idea can explain the revealing of hidden ideas. One of the most important factors can be the degree to which an idea has matured. Also, as argued by Burgelman (1983), ideas that are less related to a firm's core business have less chance for organizational attention, enhancing the likelihood of delayed announcement. Ideas far from implementation also need to go underground and take more time to show their market and technological potential, and hence should be revealed later. Failing to support such ideas limits the firm to planned ideas and may restrict their venturing activities (Covin \& Miles, 2006). As such, firms may need to prepare a suitable strategic and structural context for elaborating and revealing such ideas.

Overall, this research, as one of the first studies on the later stage of bootlegging in the novel context of a developing country, provides valuable insights into why bootleggers choose to uncover their hidden ideas. Greater understanding of this behaviour waits for future research.

\section{About the Authors}

Kamal Sakhdari is an Assistant Professor in the Faculty of Entrepreneurship at the University of Tehran, Iran. He received his $\mathrm{PhD}$ in Business and Entrepreneurship from the Queensland University of Technology (QUT) in Brisbane, Australia. His main research interests are corporate entrepreneurship, innovation management, institutional theory, and international business. He is also a member of the Australian Centre for Entrepreneurship Research (ACE) at the QUT Business School.

Erfan Jalali Bidakhavidi holds a Master's degree in Entrepreneurship from the Faculty of Entrepreneurship at the University of Tehran, Iran. His main research interests are corporate entrepreneurship, innovation management, and organizational behaviour. He has been working in the telecommunication industry for several years, and is now conducting a research project on bootlegging behaviour focusing on cultural and institutional factors.

\section{References}

Abetti, P. A. 1999. Underground Innovation in USA, Europe, and Japan. In Proceedings of the Portland International Conference on Management of Engineering and Technology (PICMET): Technology and Innovation Management. New York: IEEE.

http://dx.doi.org/10.1109/PICMET.1999.807787

Abetti, P. A. 1997. Underground Innovation in Japan: The Development of Toshiba's Word Processor and Laptop Computer. Creativity and Innovation Management, 6(3): 127-139. http://dx.doi.org/10.1111/1467-8691.00061

Amabile, T. M. 1988. A Model of Creativity and Innovation in Organizations. Research in Organizational Behavior, 10(1): 123-167.

Aram, J. D. 1973. Innovation Via the R\&D Underground. Research Management, 16(6): 24-26.

Augsdorfer, P. 1996. Forbidden Fruit: An Analysis of Bootlegging, Uncertainty, and Learning in Corporate $R \& D$. Doctoral dissertation, University of Sussex.

Augsdorfer, P. 2005. Bootlegging and Path Dependency. Research Policy, 34 (1): 1-11.

http://dx.doi.org/10.1016/j.respol.2004.09.010

Augsdorfer, P. 2008. Managing the Unmanageable. ResearchTechnology Management, 51 (4): 41-47.

http://dx.doi.org/10.1080/08956308.2008.11657513

Augsdorfer, P. 2012. A Diagnostic Personality Test to Identify Likely Corporate Bootleg Researchers. International Journal of Innovation Management, 16(1): 1250003. http://dx.doi.org/10.1142/S1363919611003532 


\section{How to Encourage Bootlegging Employees to Disclose Their Good Ideas}

\section{Kamal Sakhdari and Erfan Jalali Bidakhavidi}

Burgelman, R. A. 1983. A Process Model of Internal Corporate Venturing in the Diversified Major Firm. Administrative Science Quarterly, 28(2): 223-244.

http://dx.doi.org/10.2307/2392619

Burgelman, R. A., \& Syles, L. R. 1986. Inside Corporate Innovation: Strategy, Structure and Managerial Skills. New York: Free Press

Corbin, J., \& Strauss, A. 2014. Basics of Qualitative Research: Techniques and Procedures for Developing Grounded Theory. Thousand Oaks, CA: Sage Publications.

Covin, J., \& Miles, M. 2006. Corporate Entrepreneurship and the Pursuit of Competitive Advantage. Entrepreneurship: Theory and Practice, 23(3): 47-47.

Criscuolo, P., Salter, A., \& Ter Wal, A. L. 2013. Going Underground: Bootlegging and Individual Innovative Performance. Organization Science, 25(5): 1287-1305.

http://dx.doi.org/10.1287/orsc.2013.0856

Globocnik, D., \& Salomo, S. 2015. Do Formal Management Practices Impact the Emergence of Bootlegging Behavior? Journal of Product Innovation Management, 32(4): 505-521. http://dx.doi.org/10.1111/jpim.12215

Kannan-Narasimhan, R. P. 2014. Organizational Ingenuity in Nascent Innovations: Gaining Resources and Legitimacy through Unconventional Actions. Organization Studies, 35(4): 483-509. http://dx.doi.org/10.1177/0170840613517596

Kanter, R. M. 2000. When a Thousand Flowers Bloom: Structural, Collective, and Social Conditions for Innovation in Organization. In R. Swedberg (Ed.), Entrepreneurship: The Social Science View: 167-210. Oxford: Oxford University Press.

Knight, K. E. 1967. A Descriptive Model of the Intra-Firm Innovation Process. Journal of Business, 40(4): 478-496. http://www.jstor.org/stable/2351630

Koch, R., \& Leitner, K. H. 2008. The Dynamics and Functions of SelfOrganization in the Fuzzy Front End: Empirical Evidence from the Austrian Semiconductor Industry. Creativity and Innovation Management, 17(3): 216-226.

http://dx.doi.org/10.1111/j.1467-8691.2008.00488.x
Mainemelis, C. 2010. Stealing Fire: Creative Deviance in the Evolution of New Ideas. Academy of Management Review, 35(4): 558-578.

Masoudnia, Y., \& Szwejczewski, M. 2012. Bootlegging in the R\&D Departments of High-Technology Firms. Research-Technology Management, 55(5): 35-42. http://dx.doi.org/10.5437/08956308X5505070

Merton, R. K. 1968. Social Theory and Social Structure. New York: Simon and Schuster.

Pearson, A. 1997. Innovation Management - Is There Still a Role for "Bootlegging"? International Journal of Innovation Management, 1(2): 191-200.

http://dx.doi.org/10.1142/S1363919697000115

Ryan, B. 2005. The Problematic Nature of Organization Culture and a Changing Control Context. Strategic Change, 14(8): 431-440. http://dx.doi.org/10.1002/jsc.740

Salomo, S., \& Mensel, N. 2001. Front-End Idea Generation for Innovation: Empirical Evidence from German Industrial Corporations. In Proceedings of the Portland International Conference on Management of Engineering and Technology (PICMET): Technology and Innovation Management, 2: 117-123. New York: IEEE. http://dx.doi.org/10.1109/PICMET.2001.952011

Turner, T., \& Pennington III, W. W. 2015. Organizational Networks and the Process of Corporate Entrepreneurship: How the Motivation, Opportunity, and Ability to Act Affect Firm Knowledge, Learning, and Innovation. Small Business Economics, 45(2): 447-463. http://dx.doi.org/10.1007/s11187-015-9638-0

Yin, R. K. 2013. Case Study Research: Design and Methods. Thousand Oaks, CA: Sage Publications.

Citation: Sakhdari, K., \& Bidakhavidi, E. J. 2016. Underground Innovation: How to Encourage Bootlegging Employees to Disclose Their Good Ideas. Technology Innovation Management Review, 6(3): 5-12. http://timreview.ca/article/970

Keywords: hidden ideas, bootlegging, corporate entrepreneurship, innovation, R\&D departments, qualitative research method 